\title{
Activated Canonical Wnt Signaling in GBM is Associated with Increased Expression of Stem Cell Surface Markers
}

\author{
Samuel H. Cheshier ${ }^{1}$, Laurie Ailles ${ }^{2}$, Irving L. Weissman ${ }^{3}$, Victor Tse ${ }^{4}$, Stephen Skirboll ${ }^{5}$ \\ 1. Department of Neurosurgery and Neurology, Stanford University School of Medicine \& Lucile Packard \\ Children's Hospital 2. Department of Medical Biophysics, University of Toronto, Toronto, Ontario, \\ Canada 3. Stanford Institute of Stem Cell Biology and Regenerative Medicine, Stanford University School \\ of Medicine 4. Department of Neurosurgery, Kaiser Permanente, Redwood City, California 940635. \\ Department of Neurosurgery, Stanford University School of Medicine
}

$\square$ Corresponding author: Samuel H. Cheshier, sam@samuelcheshier.com Disclosures can be found in Additional Information at the end of the article

\section{Abstract}

Introduction: Glioblastoma multiforme (GBM) is the most common primary brain tumor in adults. Stem cells and tumor cells share similar properties, most notably the ability to selfrenew. Since tumors may arise from the transformation of normal stem cells, similar signals may regulate self-renewal in both cell types. Wnt signaling is involved in numerous developmental events, including the self-renewal of hematopoietic stem cells (HSC). We investigated Wnt signaling activity in GBM with hopes of determining if this molecule is important in GBM self-renewal.

Methods: GBM cells were isolated from six different patients. After single cell suspensions were made, the cells were co-cultured with Lentivirus containing GFP driven by a Wnt responsive promoter (OT-GFP) for 72 hours. The cells were then stained with markers of interest, including Notch 1, CD24, CD 133, CD44, and EGFRvIII, and analyzed with flow cytometry.

Results: GBM transduced with OT-GFP expressed variable amounts of the GFP marker protein. GFP expression was detected in an average of $12.8 \%$ (range $0.88-35 \%$ ) of cells initially cultured in standard media containing fetal calf serum (TM) and in an average of 5.2\% (range 0.619.83\%) of GBM cells initially cultured in media conditioned for neurosphere survival (SCM). A higher proportion of GFP+ cells expressed Notch-1, CD133, EGFRvIII, and CD44 than in GFPcells.

Conclusion: Despite advancements in surgical technique, chemotherapy, and irradiation therapy, the diagnosis of GBM continues to have a dismal prognosis. Understanding the molecular basis of the formation of GBM may offer better insights into treating this disease. We show that the Wnt signaling pathway is activated in GBM and may thus be important in tumor self-renewal.

๑) Copyright 2011

Cheshier et al. This is an open access article distributed under the terms of the Creative Commons Attribution License CC-BY 3.0., which permits unrestricted use, distribution, and reproduction in any medium, provided the original author and source are credited.
Categories: Genetics, Miscellaneous, Neurosurgery

Keywords: gfp, cell self-renewal, wnt, stem cells, glioblastoma

\section{Introduction}

How to cite this article

Cheshier S H., Ailles L, Weissman I L., et al. (March 13, 2011) Activated Canonical Wnt Signaling in GBM is Associated with Increased Expression of Stem Cell Surface Markers. Cureus 3(3): e25. DOI 10.7759 /cureus. 25 
GBM is the most common primary brain tumor in adults with an annual incidence of about 10,000 cases in the U.S. Despite advancements in diagnosis, surgical technique, radiation delivery, and medical therapy, the prognosis for patients afflicted with this tumor remains quite poor. For the past two decades, the median survival times remain less than one year, with only $1.8 \%$ of patients alive at three years post-diagnosis [1].

Intensive research has lead to a greater understanding of the molecular events, which can contribute to the formation of GBM. Most studies have focused on growth factors, cell cycle mediators, apoptosis regulators, tumor suppressors, chromosomal alterations, and angiogenic factors reviewed [2]. A key property of all tumors is their ability to self-renew. However, the factors mediating self-renewal in GBM remain poorly investigated.

Wnt signaling is involved in numerous events in animal development, including the selfrenewal of stem cells. Wnt genes encode secreted proteins that induce an intracellular signaling cascade upon binding to Frizzled receptors. The cascade leads to the inhibition of GSK-3 beta serine-threonine kinase glycogen synthase resulting in decreased phosphorylation of APC and Beta-catenin. Dephosphorylated Beta-catenin translocates to the nucleus where it serves as a trans-activator for the transcription factor TCF, leading to the transcription of several target genes including c-myc, D cyclins, and Notch. The activation of this pathway is necessary for hematopoietic stem cell and central nervous system stem cell self-renewal, and inhibition of Wnt signaling can block proliferation of chronic myelogenous leukemia progenitors [3-5]. Investigators have demonstrated the dysregulation of Wnt signaling in the development various cancers, including T-cell leukemias, blast crisis phase of chronic myelogenous leukemia (CML), acute myelogenous leukemia, breast cancer, medulloblastoma, and colon cancer [5-10]. Because stem cells and tumor cells self-renew, they likely share similar signals to mediate this event. The role of Wnt signaling in GBM is a developing topic with a limited number of studies implicating this pathway in gliomagenesis [11-14].

In our study, we investigated the role of Wnt signaling in primary GBM and gliomas by transducing freshly isolated tumor cells with lentiviral constructs containing a LEF/TCFgreen fluorescent protein (GFP) reporter (OT-GFP). This construct will express GFP only in cells with an activated Wnt pathway [3]. Furthermore, we demonstrate the expression pattern of several cell surface molecules with respect to GFP expression. The markers studied included molecules expressed on human neural stem cells (CD 133, CD24), the glioma associated growth factor EGFRvIII, cell adhesion molecule CD44, and self- renewal regulator Notch-1.

\section{Materials And Methods Obtaining tumor samples}

Six GBM [two recurrent (r)], one recurrent anaplastic oligodendroglioma (AO), one recurrent anaplastic mixed oligo-astrocytoma (AMOA), one anaplastic oligodendroglioma (AO), and one WHO II mixed oligo-astrocytoma (MOA) were obtained from patients undergoing surgical resections. Tissue was collected as per research protocol approved by Stanford University Institutional Review Board.

\section{Single cell suspensions}

Fresh tumor was washed in sterile ice cold HBSS + 1\% calf serum. The sample was then minced with sterile scissors and then digested with $0.1 \%$ collagenase, $0.1 \%$ Hyaluronidase, and $0.01 \%$ DNASE I with $30 \mathrm{mM} \mathrm{CaC1}_{2}$ in $\mathrm{HBSS}$ for one hour at $37^{\circ} \mathrm{C}$ with frequent mixing during incubation. The cells were then spun down and passed serially through a 70 micron and then 40 micron nylon filter. The cells were then resuspended in HBSS and counted using Trypan Blue staining. 


\section{Lentiviral transduction}

The above cells were split into two groups containing equal numbers of cells (2 -10 X 106), spun down and resuspended in tumor media [TM, DMEM $+20 \%$ FCS] or neural stem cell media [SCM, Neurobasal media, 1 X B27, EGF $20 \mathrm{ng} / \mathrm{ml}$, FGF $20 \mathrm{ng} / \mathrm{ml}$, heparin $2 \mathrm{mg} / \mathrm{ml}$ Glutamine $2 \mathrm{mM}$ ]. The cells in each condition were then split into three wells at a cell concentration of 1 - 2 million cells / $\mathrm{ml}$ and then the following lentivirus were added: 1) OT-GFP (the Wnt responsive promoter); 2) pgK-GFP (constitutively active promoter) which served as our positive control; and 3) No vector added which served as our negative control. Viral stocks were used to a final concentration of $1 / 100$ with an average titer of $4.5 \times 108$ in the OT-GFP virus and in $2.4 \times 108$ the pgK-GFP virus. Cells were cocultured with virus for 72 hours at $37^{\circ} \mathrm{C}$ in $5 \% \mathrm{CO} 2$. On the second day, fresh EGF and FGF were added to the SCM condition.

\section{Fluorescence activated cell sorting (FACS) staining and analysis}

After coculture with virus, the floating tumor spheres of SCM condition were placed in a FACS tube and washed $3 \mathrm{X}$ with sterile HBSS, and the adherent cells from SCM condition were washed with sterile HBSS 3X. The tumor spheres and adherent cells were trypsinized $(0.05 \%$ trypsin with EDTA $37^{\circ} \mathrm{C}$ for five minutes washed, tyrpsin inhibitor added and washed) and placed in HBSS on ice. In the TM condition, the adherent cells were washed 3X with sterile HBSS trypsinized as above and placed in FACS tube with HBSS $+2 \%$ FCS. The cells were then stained with antibodies. All antibody stainings were performed for $30 \mathrm{~min}$. on ice. After each antibody stain, the cells were washed by filling the FACS tube with ice cold HBSS and spinning down the cells with cytocentrifuge. The OT-GFP and pgk-GFP transduced cells were stained with Mouse anti-human Notch-1, and/or Rabbit anti-human EGFRvIII. Then with secondary antibodies, Goat anti-mouse TxRd and Goat anti-rabbit PE. 5\% normal mouse serum was then used to block any remaining anti-mouse binding from the secondary. The cells were then incubated with the following antibodies: Mouse anti-human CD 133 (isoforms 1/2) APC, Mouse anti-human CD44 biotin, Mouse anti-human CD45 Cy5PE, +/- Mouse anti-human CD24 PE. The cells were incubated with strepavidin-Cy7PE for 15-30 min. and after a final wash the SCM cells were resuspended in HBSS + 0.5 X B27, EGF, Heparin, and Glutamine + P1(1 ug/ml) and TM cells were resuspended in HBSS $+2 \%$ FCS + PI $(1 \mathrm{ug} / \mathrm{ml})$. The cells not transduced with any vector were washed, resuspended in HBSS +2\% FCS + PI ( $1 \mathrm{ug} / \mathrm{ml})$ and served as our negative control for GFP expression and antibody staining. Flow cytometry was performed on a Becton-Dickenson FACS Diva. Propidium iodide (PI) and CD45 were used in all samples to exclude non-viable cells and hematopoietic cells, respectively. The data was analyzed using FloJo ${ }^{\circledR}$ software Treestar. Inc. An outline of our overall experimental strategy can be seen in Figure 1. 


\section{Cureus}

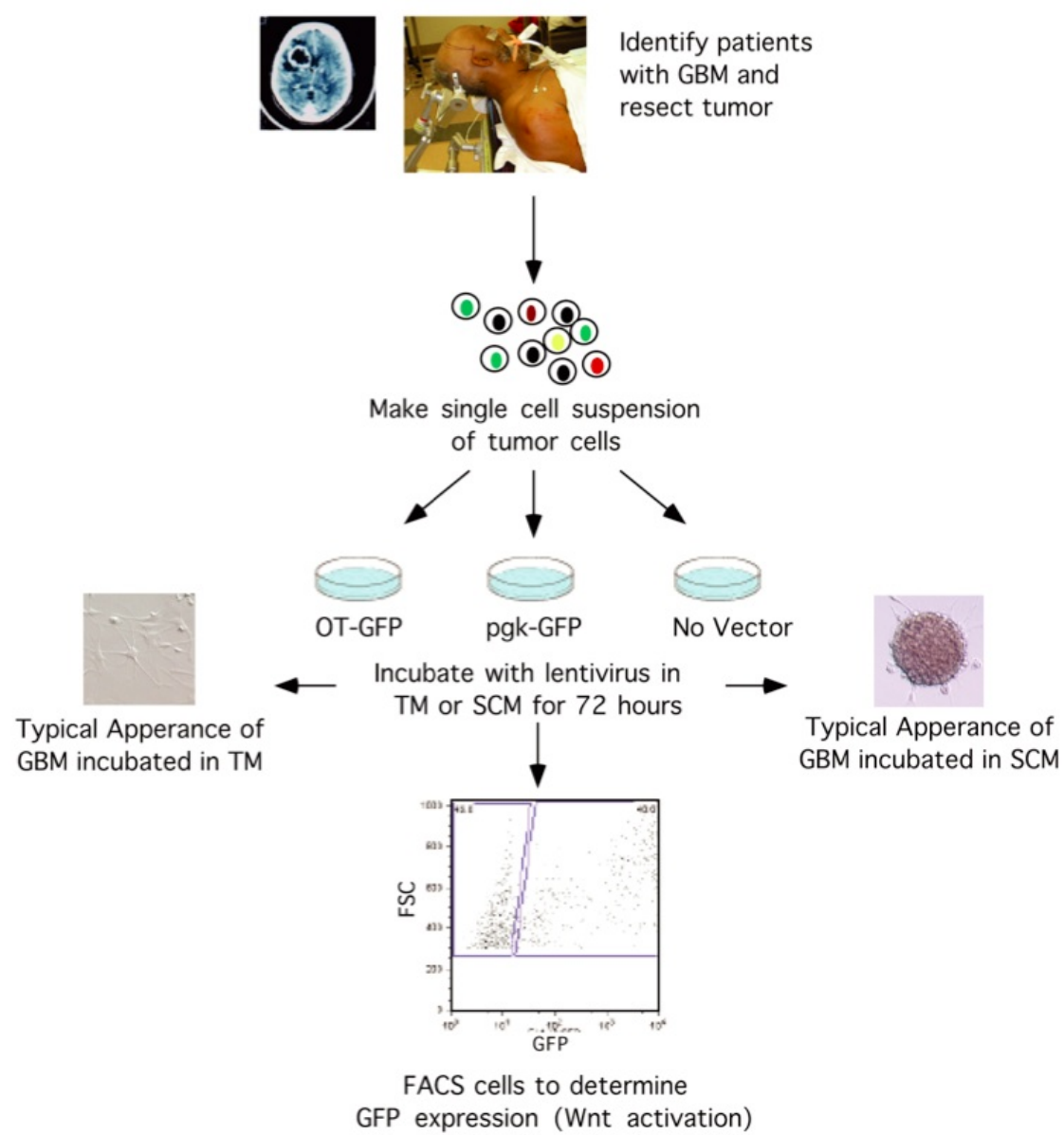

\section{FIGURE 1: Outline of experimental protocol}

Tumors were freshly isolated from patients and disassociated into single cell suspensions. The cells were then incubated in TM or SCM with lentivirus containing either GFP driven by Wnt responsive promoter (OTGFP), GFP driven by constitutively active promoter (pgk-GFP), or no vector. After 3 days of culture, the cells were stained with antibodies to assess cell surface molecules and FACS was used to determine GFP and cell surface protein expression.

\section{Results}

We analyzed a total of nine tumors (six GBM, one AMOA, one AO, and one WHO II MOA) for OTGFP expression. As seen in Figure 2, GFP could be readily detected in OT-GFP transduced tumor cells by FACS indicating canonical Wnt signal activity in these cells. 


\section{Cureus}
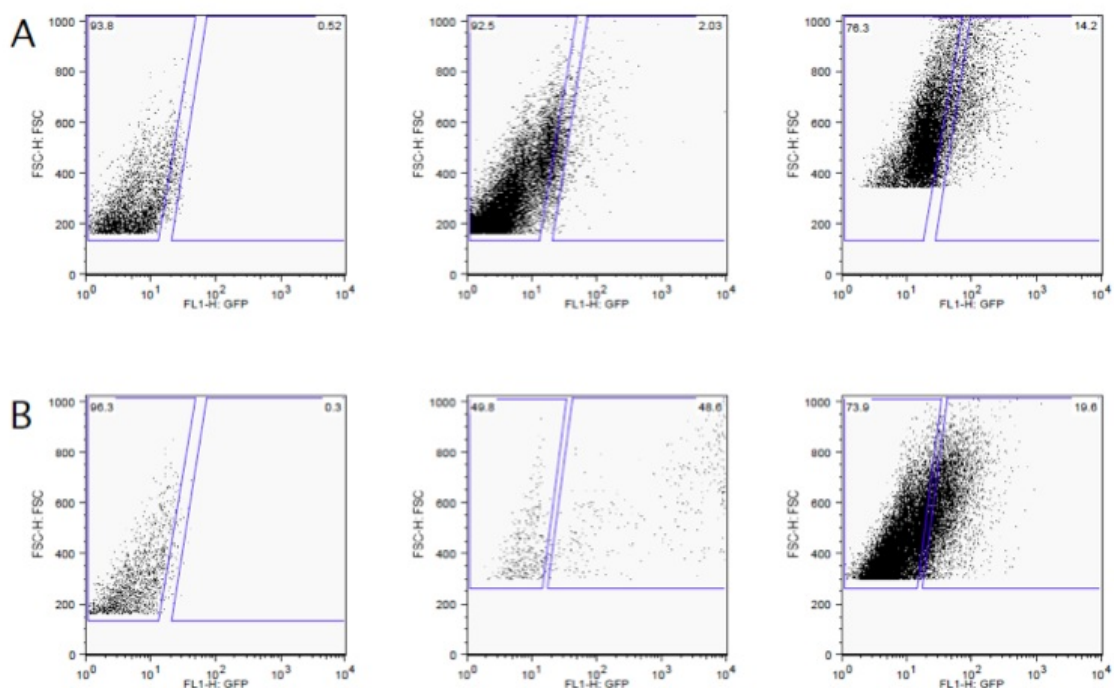

\section{FIGURE 2: Representative FACS plots demonstrating GFP signal in GBM cells}

Representative FACS plots demonstrating GFP signal in GBM cells grown in either tumor media (row A) or neural stem cell media (row B), and transduced with either pgk-GFP, used as positive control due to its constitutively active promoter (middle column), or with OT-GFP as the experimental vector to show cells with activated Wnt signaling pathway (right column). The left column shows cells that did not undergo transduction. All cells shown were PI negative and CD45 negative, the percent of which was not significantly affected by whether transduction was performed or not

We analyzed for contaminant GFP signal with the cell surface proteins, CD 133, Notch-1, EGFRV3, CD44, and CD24. Each of these markers has been implicated as a potential stem cell marker (Tables 1, 2). In each instance, with the exception of CD24, there was an increase in stem cell associated marker with GFP expression. 


\section{Cureus}

\begin{tabular}{|c|c|c|c|c|c|c|c|c|c|c|c|}
\hline $1 \mathrm{M}$ & GFP+ & $\begin{array}{l}\text { GFP+ } \\
\text { Notch+ }\end{array}$ & $\begin{array}{l}\text { GFP- } \\
\text { Notch+ }\end{array}$ & $\begin{array}{l}\text { GFP+ } \\
\text { CD133+ }\end{array}$ & $\begin{array}{l}\text { GFP- } \\
\text { CD133+ }\end{array}$ & $\begin{array}{l}\text { GFP+ } \\
\text { EGFRvIII+ }\end{array}$ & $\begin{array}{l}\text { GFP- } \\
\text { EGFRvIII+ }\end{array}$ & $\begin{array}{l}\text { GFP+ } \\
\text { CD44+ }\end{array}$ & $\begin{array}{l}\text { GFP- } \\
\text { CD44+ }\end{array}$ & $\begin{array}{l}\text { GFP+ } \\
\text { CD24+ }\end{array}$ & $\begin{array}{l}\text { GFP- } \\
\text { CD24+ }\end{array}$ \\
\hline GBM-1 & 30.7 & 7.4 & 0.15 & 22.3 & 0.11 & 65.5 & 0.62 & 62.5 & 2.18 & nd & nd \\
\hline GBM(r)-2 & 36 & 44.5 & 8.4 & 44.3 & 7.9 & 22.9 & 0.4 & 93 & 61.6 & nd & nd \\
\hline GBM-3 & 0.88 & 30.2 & 15 & 15.1 & 7.2 & nd & nd & 99.2 & 89.1 & 98.7 & 91.9 \\
\hline GBM(r)-4 & 1.19 & 0 & 13.6 & 0 & 2.5 & nd & nd & 0 & 6.7 & 75 & 39.2 \\
\hline GBM-5 & 6.75 & 7.27 & 0.63 & 65.2 & 2.1 & 11.1 & 0.03 & 42 & 3.19 & nd & nd \\
\hline GBM-6 & 1.2 & 2.4 & 1.27 & 2.66 & 1.6 & 0.68 & 0.27 & 92.5 & 52.9 & nd & nd \\
\hline$A M O A(r)$ & 69.8 & nd & nd & 0.98 & 0.22 & 1.39 & 1.77 & 9.4 & 3.97 & nd & nd \\
\hline $\mathrm{AO}(\mathrm{r})$ & 3.44 & 68.5 & 2.25 & 7.8 & 1.69 & 47.1 & 0.75 & 94.2 & 57.3 & nd & nd \\
\hline $\begin{array}{l}\text { WHO II } \\
\text { MOA }\end{array}$ & 21.6 & nd & nd & 9.89 & 4.1 & 74 & 14.7 & 94.3 & 69.1 & 99.7 & 91.3 \\
\hline
\end{tabular}

\section{TABLE 1: Data table showing percentage of viable, non-hematopoietic cells that}

express each of the tumor and stem cell surface markers in either GFP positive or

\section{negative cells}

Data table showing, for each tumor incubated in tumor media (TM), the percentage of viable, non-hematopoietic cells (PI negative, CD45 negative) that express each of the tumor and stem cell surface markers in either GFP positive or negative cells. In the second column, GFP+ represent the \% of living nonhematopoietic cells, which express GFP. The remaining columns contain the $\%$ of GFP+ or GFP- cells expressing each cell surface molecule. $n d=$ staining not done. AMOA = Anaplastic Mixed Oligo/Astrocytoma. $\mathrm{AO}=$ Anaplastic Oligodendroglioma. $\mathrm{AMOA}=$ Anaplastic Mixed Oligo/Astrocytoma. $(r)=$ recurrent tumor. 


\section{Cureus}

\begin{tabular}{|c|c|c|c|c|c|c|c|c|c|c|c|}
\hline SCM & GFP+ & $\begin{array}{l}\text { GFP+ } \\
\text { Notch+ }\end{array}$ & $\begin{array}{l}\text { GFP- } \\
\text { Notch+ }\end{array}$ & $\begin{array}{l}\text { GFP+ } \\
\text { CD133+ }\end{array}$ & $\begin{array}{l}\text { GFP- } \\
\text { CD133+ }\end{array}$ & $\begin{array}{l}\text { GFP+ } \\
\text { EGFRvIII+ }\end{array}$ & $\begin{array}{l}\text { GFP- } \\
\text { EGFRvIII+ }\end{array}$ & $\begin{array}{l}\text { GFP+ } \\
\text { CD44+ }\end{array}$ & $\begin{array}{l}\text { GFP- } \\
\text { CD44+ }\end{array}$ & $\begin{array}{l}\text { GFP+ } \\
\text { CD24+ }\end{array}$ & $\begin{array}{l}\text { GFP- } \\
\text { CD24+ }\end{array}$ \\
\hline GBM-1 & 9.83 & 2.05 & 0.11 & 13.2 & 0.29 & 62.5 & 3.5 & 4.1 & 0.34 & nd & nd \\
\hline $\begin{array}{l}\text { GBM(r)- } \\
2\end{array}$ & 5.02 & 14.2 & 0.31 & 21.8 & 0.36 & 10.5 & 0 & 22 & 1.2 & nd & nd \\
\hline GBM-3 & 13 & 7.5 & 0.33 & 3.1 & 0.4 & nd & nd & 13.4 & 8.7 & 99 & 91.9 \\
\hline GBM(r)-4 & 0.61 & 28.5 & 0 & 28.5 & 8.7 & nd & nd & 71.4 & 8.6 & 90.4 & 12.9 \\
\hline GBM-5 & 4.01 & 2.98 & 0.044 & 57.8 & 1.36 & 18.3 & 0.047 & 0.37 & 0.014 & nd & nd \\
\hline GBM-6 & 0.82 & 69.6 & 2.4 & 0.46 & 1.64 & 0.13 & 0.27 & 2.66 & 3.08 & nd & nd \\
\hline AMOA(r) & 15.2 & nd & nd & 0.48 & 0.28 & 3.3 & 4.1 & 88.2 & 13.5 & nd & nd \\
\hline $\mathrm{AO}(\mathrm{r})$ & 0 & na & 0.4 & na & 0.15 & na & 0.15 & na & 99.8 & nd & nd \\
\hline MOA & 30.7 & nd & nd & 3.03 & 1.11 & 80.8 & 53.5 & 5.19 & 2.96 & 99.9 & 95.3 \\
\hline
\end{tabular}

TABLE 2: Data table showing percentage of viable, non-hematopoietic cells (PI negative, CD45 negative) that express each of the tumor and stem cell surface markers in either GFP positive or negative cells

Data table showing, for each tumor incubated in neural stem cell media (SCM), the percentage of viable, non-hematopoietic cells (PI negative, CD45 negative) that express each of the tumor and stem cell surface markers in either GFP positive or negative cells. In the second column, GFP+ represent the \% of living non-hematopoietic cells, which express GFP. The remaining columns contain the $\%$ of GFP+ or GFP- cells expressing each cell surface molecule. nd = staining not done, na = non applicable. See Table 1 for the other abbreviations.

\section{Discussion}

The canonical Wnt pathway has been implicated in self-renewal in a number of stem cell systems as well as in the pathogenesis of several tumor types. We demonstrated that an activated Wnt pathway is present in each glioma tested at some level. Furthermore, the presence of Wnt signaling correlated with a higher expression of several stem cell associated markers, including CD 133, Notch 1, EGFRV3, and CD44. Interestingly, this pattern was not revealed in CD24. This may be due to a low number of tumors expressing CD24 (three of nine). However, given that CD24 negative/low expression is seen in human CNS stem cells, the fact that this trend is seen in OT-GFP expressing gliomas is indeed consistent with CNS stem cells (15).

Given the fact that we expected SCM to enrich for stem cells relative to TM, our finding of more GFP positive cells in the TM was unexpected. However, we feel this is most likely due to the depleted nature of SCM relative to TM. SCM is a defined media and most tumor cells die upon initial culturing. The calf serum in TM contains many undefined growth factors that improve the viability of primary cultures. Furthermore, the short time the cells were in culture probably did not allow the expansion of brain tumor stem cells, thus, the fewer percentage of GFP positive cells in SCM. Finally, canonical Wnt signaling is seen in a wide array of cellular 
processes, and the signal seen in the TM cultured tumor cells may non-self-renewal functions. However, our observation that GFP positive cells were enriched for putative stem cell markers relative to GFP negative cells, even in the TM condition, supports our hypothesis that canonical Wnt signaling is reflective of "stem cellness".

Future studies ascertaining the functional differences between glioma cells with activated Wnt pathway versus glioma cells without Wnt signaling would be revealing. Specifically, cells with and without activated Wnt signal could be prospectively isolated and tested for tumor sphere forming efficiency in vitro and tumor formation in vivo by transplantation into the brains of immune-compromised mice. If canonical Wnt signaling in GBM enriches for brain tumor stem cells, then these cells should possess greater tumor sphere formation ability and have selective growth in the brains of transplanted mice.

\section{Conclusions}

In conclusion, this manuscript demonstrates that GBM with activated canonical Wnt pathway (as indicated by our lentiviral reporters), enriches for several cell surface markers that are known to be expressed on stem cells, thus implicating the Wnt signaling pathway in the pathogenesis of this disease.

\section{Additional Information \\ Disclosures}

Human subjects: Consent was obtained by all participants in this study. The Stanford University Institutional Review Board issued approval N/A. Animal subjects: All authors have confirmed that this study did not involve animal subjects or tissue. Conflicts of interest: In compliance with the ICMJE uniform disclosure form, all authors declare the following:

Payment/services info: All authors have declared that no financial support was received from any organization for the submitted work. Financial relationships: All authors have declared that they have no financial relationships at present or within the previous three years with any organizations that might have an interest in the submitted work. Other relationships: All authors have declared that there are no other relationships or activities that could appear to have influenced the submitted work.

\section{References}

1. Kleihues P, Burger PC, Plate KH, Ohgaki H, Cavenee WK: Glioblastoma. Pathology and Genetics of Tumours of the Central Nervous System. Kleihues P, Cavenee WK (ed): International Agency for Research on Cancer, Lyonn France; 1997. 16-24.

2. Adamson C, Kanu OO, Mehta AI, et al.: Glioblastoma multiforme: a review of where we have been and where we are going. Expert Opin Investig Drugs . 2009, 18:1061-83.

3. Reya T, Duncan AW, Ailles L, et al.: A role for Wnt signalling in self-renewal of haematopoietic stem cells. Nature . 2003, 423:409-14.

4. Kalani MY, Cheshier SH, Cord BJ, et al.: Wnt-mediated self-renewal of neural stem/progenitor cells. Proc Natl Acad Sci USA . 2008, 105:16970-75.

5. Jamieson CH, Ailles LE, Dylla SJ, et al.: Granulocyte-macrophage progenitors as candidate leukemic stem cells in blast-crisis CML. NEJM. 2004, 351:657-67.

6. Majeti R, Becker MW, Tian Q, et al.: Dysregulated gene expression networks in human acute myelogenous leukemia stem cells. Proc Nat! Acad Sci US A . 2009, 106:3396-3401.

7. Kawaguchi-Ihara N, Murohashi I, Nara N, Tohda S: Promotion of the self-renewal capacity of human acute leukemia cells by Wnt3A. Anticancer Res. 2008, 28:2701-04.

8. Northcott PA, Korshunov A, Witt H, Hielscher T, Eberhart CG, Mack S, Bouffet E, Clifford SC, Hawkins CE, French P, Rutka JT, Pfister S, Taylor MD: Medulloblastoma comprises four distinct molecular variants. J Clin Oncol. 2011, 29:1408-14. 10.1200/JCO.2009.27.4324

9. Mohinta S, Wu H, Chaurasia P, Watabe K: Wnt pathway and breast cancer. Front Biosci. 2007, 


\section{Cureus}

12:4020-33.

10. Schneikert J, Behrens J: The canonical Wnt signalling pathway and its APC partner in colon cancer development. Gut. 2007, 56:417-25.

11. Kornblum HI: A multipronged approach to the identification and study of an important oncogene in GBM. Cancer Cell. 2010, 17:417-18.

12. Lottaz C, Beier D, Meyer K, et al.: Transcriptional profiles of CD133+ and CD133glioblastoma-derived cancer stem cell lines suggest different cells of origin. Cancer Res. 2010, 70:2030-40.

13. Wang J, Wang X, Jiang S, et al.: Partial biological characterization of cancer stem-like cell line (WJ(2)) of human glioblastoma multiforme. Cell Mol Neurobiol . 2008, 28:991-1003.

14. Yu JM, Jun ES, Jung JS, et al.: Role of Wnt5a in the proliferation of human glioblastoma cells . Cancer Lett. 2007, 2578:172-81.

15. Uchida N, Buck DW, He D, et al.: Direct isolation of human central nervous system stem cells. Proc Natl Acad Sci USA . 2000, 97:14720-25. 